PERSPEKTIF, 9 (2) (2020): 418-427

DOI: https://doi.org/10.31289/perspektif.v9i2.3884

PERSPEKTIF

Available online http://ojs.uma.ac.id/index.php/perspektif

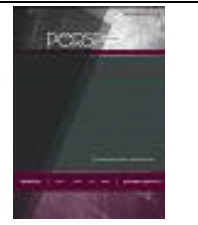

\title{
Pengelolaan Kawasan Wisata Suku Anak Dalam Berbasis Kearifan Lokal
}

\section{Management of Children in Local Tourism Regions Based on Local Wisdom}

\author{
Syafik Wazan, Retno Sunu Astuti, Kismartini \& Teuku Afrizal* \\ Magister Administrasi Publik, Fakultas Ilmu Sosial dan Ilmu Politik, \\ Universitas Diponegoro, Indonesia
}

Diterima: 15 Juni 2020; Disetujui: 12 Juli 2020; Dipublish: 18 Juli 2020

\begin{abstract}
Abstrak
Tujuan dari penelitian ini Untuk menganalisa Pengelolaan Kawasan Wisata Suku Anak Dalam serta mengetahui kendala pengelolaan kawasan wisata Suku Anak Dalam di Taman Nasional Bukit Duabelas Kabupaten Sorolangun Kabupaten Jambi. Teori menggunakan pendapat Cox (1985) dalam Pitana (2009) tentang pengelolaan pariwisata harus memperhatikan prinsip-prinsip seperti Pembangunan, Preservasi, Pengembangan, Pelayanan dan Regulasi/kepastian hukum. Metode penelitian menggunakan pendekatan kualitatif deskriptif. Penelitian ini dilaksanakan di kawasan pemukiman Suku Anak Dalam Kabupaten Sorolangun Propinsi Jambi. Pengumpulan data menggunakan observasi, wawancara (FGD), dan Dokumentasi/Penelitian Serupa. Hasil penelitian Pengelolaan kawasan wisata Suku Anak Dalam (SAD) sudah memberikan kenyaman kepada para pengunjung tanpa mengusik atau mengganggu ekosistem atau keaslian dari tempat wisata tersebut. Dengan adanya pengelolaan wisata edukasi ini akan menambah pendapatan asli daerah dalam bidang kepariwisataan. Hal inilah yang harus dipertahankan agar nantinya muncul objek wisata yang lainnya. Hanya saja perlu adanya sebuah peraturan daerah untuk pengenbangan wisata khsususnya kawasan wisata suku anak dalam agar perawatannya dapat dirasakan secara langsung kepada masyarakat.

Kata Kunci: Pengelolaan Pariwisata, Suku Anak Dalam, Kearifan Lokal
\end{abstract}

\section{Abstract}

The purpose of this study is to analyze the Management of the Children in the Tourism Area of the Children in the Tribe and to find out the obstacles in the management of the Children in the Tourism Area in the Bukit Duabelas National Park, the Sorolangun Regency, the Jambi Regency. The theory uses the opinion of Cox (1985) in Pitana (2009) on tourism management must pay attention to principles such as Development, Preservation, Development, Service and Regulation / legal certainty. The research method uses a descriptive qualitative approach. This research was carried out in the settlement of the Children of the Tribe in the Sorolangun Regency, Jambi Province. Data collection uses observation, interviews (FGD), and Documentation / Similar Research. The results of research on the management of the Suku Anak Dalam tourism area (SAD) have provided comfort to visitors without disturbing or disturbing the ecosystem or the authenticity of the tourist attractions. With the existence of this educational tourism management will increase the original income of the region in the field of tourism. This must be maintained so that later other tourism objects will emerge. It's just that there is a need for a regional regulation for the development of special tourism areas for children in the tribe so that treatment can be felt directly to the community.

Keywords: Tourism Management, Children In Tribe, Local Wisdom

How to Cite: Wazan, S. Astuti, R.S. Kismartini \& Afrizal, T. (2020). Pengelolaan Kawasan Wisata Suku Anak Dalam Berbasis Kearifan Lokal.PERSPEKTIF, 9(2): 418-427

*Corresponding author:

ISSN 2085-0328 (Print)

E-mail: teukurian@lecturer.undip.ac.id

ISSN 2684-9305(Online) 


\section{PENDAHULUAN}

Pariwisata tersebar luas dalam masyarakat manusia ini terlihat dari banyaknya wisatawan yang mengunjungi tempat wisata dan sangat sedikit tempat yang belum dikunjungi wisatawan. Akibatnya, pariwisata memiliki potensi untuk mempengaruhi semua umat manusia. Selain itu, pariwisata melibatkan kontak antar budaya. Di mana para wisatawan mengunjungi tempat-tempat wisata dan dari sana pariwisata memberikan konstribusi terhadap perubahan masyarakat dan budaya. Wisatawan mengunjungi sebuah perjalanan berdasarkan beberapa pertimbangan yaitu, biaya, aksesibilitas, fasilitas yang sesuai dan memadai, keamanan, dan sebagainya (Pitana, 2009).

Pengelolaan itu sendiri adalah, mengendalikan atau menyelenggarakan berbagai sumber daya secara berhasil guna untuk mencapai sasaran. Darsoprajitno (2002) mengenai hal ini, McKean dalam Picard (2006) mengatakan uang dan pariwisata merangsang orang Bali mempertahankan berbagai tradisi yangterancam punah, sambil mengalahkan kreativitas seni budayanya dan lebih jauh lagi rasa kagum pengunjung asing memperkuat jati diri berikut kebanggaan orang Bali. Di sini pariwisata memang berperang penting dalam pertumbuhan ekonomi masing - masing individu/kelompok masyarakat melihat adanya kesempatan yang berpeluang untuk menambah perekonomian.

Dalam pariwisata ada tiga aktor penggerak pariwisata, aktor tersebut adalah insan-insan pariwisata yang ada dalam berbagai sektor. Secara umum,insan pariwisata dikelompokkan dalam tiga pilar utama, yaitu: (1) pemerintah, (2) swasta, dan (3) masyarakat yang termasuk pemerintah adalah pada bagaianwilayah administrasi, mulai dari pemerintah pusat, propinsi, kabupaten, kecamatan dan seterusnya. Selanjutnya dalam kelompok swasta adalah asosiasiusaha pariwisata dan para pengusaha. Sedangakan masyarakat adalah masyarakatumum yang tinggal di sekitar objek wisata, sebagai pemilik sah dari berbagai sumberdaya yang merupakanmodal pariwisata seperti kebudayaan (McKean dalam Picard (2006)

Sektor pariwisata yang ada harus dikelola oleh orang-orang yang ahli kepariwisataan. Seperti yang dikemukakan Salim dalam Damanhuri (2015) bahwa berapa banyak modal yang dimiliki pembangunan tidak akan terlaksana kecuali disertai dengan sumber daya managerial yang mampu mengelola modal itu untuk pembangunan.

Sumber daya managerial di sini adalah sumber daya manusia dimana masyarakat lokal berpengaruh dalam pengembangan objek wisata yang ada. Kesiapan dari masyarakat lokal mempengaruhi laju pertumbuhan dari objek wisata itu sendiri. Masyarakat adalah kesatuan hidup manusia yang berinteraksi menurut suatu sistem adat istiadat tertentu yang bersifat kontinu dan yang terikat oleh suatu rasa identitas bersama. Setiap masyarakat memiliki kebudayaan, konsep kebudayaan sendiri adalah keseluruhan sisitem gagasan, tindakan dan hasil karya manusia dalam kehidupan masyarakat yang dijadikan milik diri manusia dengan belajar (Koentjaraningrat, 2009).

Sumber daya managerial yang mengelola pariwisata memiliki proses pelaksanaan dan peraturan-peraturan tersendiri. Dari adanya proses pelaksanaan dan peraturan-peraturan itu, maka timbul kebijakan pariwisata. Kebijakan pariwisata yaitu segala sesuatu yang menyangkut tindakan instansi pemerintah dan badan atau organisasi masyarakat yang mempengaruhi kehidupan kepariwisataan itu sendiri (Kusuma, 2016) Jika kebijakan pariwisata tidak didukung dengan penuh maka akan berdampak buruk bagi pertumbuhan pariwisata. Pasal 3 peraturan pemerintah Republik Indonesia nomor 67 tahun 1996 mengatur lebih lanjut mengenai penyelenggaraan kepariwisataan. Dalam pasal tersebut dinyatakan bahwa kepariwisataan harus dilaksanakan dengan memperhatikan hal-hal berikut: 1) Kemampuan untuk mendorong dan meningkatkan perkembangan kehidupan ekonomi dan sosial budaya; 2) Nilai-nilai agama, adat istiadat, pandangan, dan nilai-nilai yang hidup dalam masyarakat; 3) Kelestarian budaya dan mutu lingkungan hidup; 4) Kelangsungan usaha pariwisata.

Industri pariwisata apabila ditinjau dari segi budaya, secara tidak langsung memberikan peran penting bagi perkembangan budaya Indonesia karena dengan adanya suatu objek wisata maka dapat memperkenalkan keragaman budaya yang dimiliki suatu negara seperti kesenian tradisional, upacara-upacara 
agama atau adat yang menarik perhatian wisatawan asing dan wisatawan Indonesia. (Pendit, 1999) Industri pariwisata yang berkembang dengan pesat memberikan pemahaman dan pengertian antar budaya melalui interaksi pengunjung wisata (turis) dengan masyarakat lokal tempat daerah wisata tersebut berada. Hal tersebut menjadikan para wisatawan dapat mengenal dan menghargai budaya masyarakat setempat dan juga memahami latar belakang kebudayaan lokal yang dianut oleh masyarakat tersebut (Suharyanto, et.al., 2019; Lubis, et.al., 2020).

Secara khusus Putra (2006) mendefinisikan kearifan lokal sebagai: kearifan lokal adalah seperangkat pengetahuan dan praktik-praktik baik yangberasal dari generasigenerasi sebelumnya maupun dari pengalaman berhubungan dengan lingkungan dan masyarakat lainnya milik suatu komunitas di suatu tempat, yang digunakan untuk menyelesaikan baik dan benar berbagai persoalan dan atau kesulitan yang dihadapi. Kearifan lokal berasal dari nilai-nilai adat istiadat, nilai-nilai keagamaan dan budaya lokal yang secara alami terbentuk dalam suatu kelompok masyarakat untuk beradaptasi dengan lingkungan sekitar (Vitasurya, 2016)

Kearifan lokal menjadi suatu ciri khas masing-masing daerah yang berpotensi untuk mendukung pengembangan suatu daerah. Potensi budaya dan kearifan lokal dalam pengembangan pariwisata menjadi bagian dari produk kreativitas manusia yang memiliki nilai ekonomi. Salah satu upaya pengembangan pariwisata berbasis budaya dan kearifan lokal adalah pengelolaan kawasan wisata Suku Anak Dalam di Propinsi Jambi.

Provinsi Jambi memiliki luas wilayah $50.058,16 \mathrm{~km} 2$ dengan jumlah penduduk

Tabel 1
3.406.178 jiwa, dengan memiliki banyak suku yang mendiaminya, di antaranya adalah Suku Kerinci, Suku Kubu, Suku Batin, Suku Melayu, dan beberapa suku minoritas lainnya. Sukusuku tersebut menyebar di 9 kabupaten, 2 kota, 138 kecamatan, 163 kelurahan, dan 1.398 desa, yang umumnya mendiami di wilayah pinggiran sungai batang hari sebagai pusat perekonomian dari masa lalu hingga masa sekarang.

Kabupaten Sorolangun Propinsi Jambi merupakan salah satu wilayah yang dianugrahi alam yang indah, cuaca yang sejuk dan nyaman. Kabupaten Sorolangun merupakan salah satu kabupaten yang ditempati oleh suku orang dalam yang memiliki daya tarik wisata berupa budaya pemandangan alam maupun kehidupan agraris masyarakat. Suku Anak Dalam bertempat di kawasan di Taman Nasional Bukit Duabelas. Luas wilayah hunian masyarakat Suku Anak Dalam di TamanNasional Bukit Duabelas berdasarkan surat keputusan dari Menteri Kehutanan dan Perkebunan pada tanggal 20 Agustus tahun 2000 seluas 60.500 hektar yang dimaksudkan untuk beberapa tujuan, diantaranya; 1)Sebagai ruang hidup Suku Anak Dalam, 2) Melindungi keanekaragaman hayati baik hewan maupun tumbuhan di dalamnya. Dari keputusan inipemerintah ingin memberikan kewenangan pada Suku Anak Dalam untuk mengolah hutan namun tetap punya peran penting dalam menjaga kelestarian hutan.

Berdasarkan data Biro Pusat Statistik, jumlah Suku Anak Dalam di Jambi di Kabupaten Sarolangun berjumlah 3.198 jiwa yang tersebar di beberapa lokasi di kawasan Taman Nasional Bukit Duabelas. Untuk lebih jelasnya Jumlah Suku Anak Dalam berdasarkan jenis kelamin di Kabupaten Sarolangun di Provinsi Jambi dapat dilihat pada tabel 1 .

Jumlah Suku Anak - Dalam Berdasarkan Jenis Kelamin di Provinsi Jambi

\begin{tabular}{llll}
\hline \multirow{2}{*}{ Kabupaten/ Kota } & Jenis Kelamin & & \multirow{2}{*}{ Jumlah } \\
\cline { 2 - 4 } & Laki -laki & Perempuan & \\
\hline Merangin & 430 & 435 & 865 \\
\hline Sorolangun & 557 & 564 & $\mathbf{1 . 1 2 1}$ \\
\hline Batanghari & 45 & 36 & 81 \\
\hline Tanjab Barat & 28 & 30 & 58 \\
\hline Tebo & 430 & 397 & 827 \\
\hline Bungo & 143 & 153 & 296 \\
\hline Jumlah & 1.633 & 1.615 & 3.248 \\
\hline
\end{tabular}

Sumber: BPS Kabupaten Sarolangun 2015 
Dapat dianalisa dari hasil tabel 1, maka jumlah populasi terbanyak untuk Suku Anak Dalam ada di Kabupaten Sorolangun dengan total polulasi 1.121 orang, hal ini menandakan kualitas hidup mereka sangat aman meskipun pengunjung pariwisata berdatangan untuk melihat secara langsungkehiduan sehari-hari mereka.

Suku Anak Dalam (SAD) atau juga sering disebut sebagai Suku Kubu atau Suku Rimba yang menetap di Taman Nasional Bukit Duabelas, kehidupannya masih terikat kuat dengan adat istiadat danketergantungan pada hasil hutan/alam dan binatang buruan. Istilah Kubu disini memiliki dua arti dalam bahasa Melayu Jambi yaitu tempat persembunyian dan bodoh atau biasa kita kenal sebutan 'kampungan 'Ndeso' dan lain sebagainya. Mereka saat ini enggan disebut sebagai Orang Kubu, dan lebih menyukai menyebut dirinya sebagai "Anak Dalam", "Orang Rimbo" atau "Orang Kelam", sedangkan orang desa di sekitarnya disebut "Orang Terang".

Sampai sekarang, peradaban Suku Anak Dalam tetap mempertahankan gaya hidupnya secara tradisional dan turun-temurun sejak dari nenek-moyang mereka. Walaupun tekanan dari luar sangat kuat untuk merubah pola kehidupan tradisional ke pola hidup modern,namun kelompok minoritas Suku Anak Dalam tetap berpola hidup tradisional. Untuk memenuhi kebutuhan hidup, masyarakat Suku Anak Dalam harus mencari dari hasil bumi yang ditemukan di kawasan hutan Taman Nasional Bukit Duabelas.

Menganalisa data pengunjung wisatawan suku anak dalam cukup memprihatinkan, data pengunjung menunjukkan bahwa wisata suku anak dalam ini kurang menarik perhatian masyarakat untuk wisata edukasi. Disebut wisata edukasi karena dengan melihat budaya suku anak dalam kita bisa mempelajari kehidupan manusia sebelum zaman modern memasuki peradaban. Pengelolaan kawasan wisata Suku Anak Dalam (SAD) ini harus lebih ditingkatkan untuk mengupayakan peningkatan pengunjung wisatawan lokal maupun manca negara. Dengan adanya pengelolaan yang baik dari polisi hutan/masyarakat lokal dan pemerintah akan memberikan sumbangan pendapatan pada kas daerahmelalui retribusi kawasan wisata.

Kawasan hunian Suku Anak Dalam ini sangat potensial untuk dikembangakan sebagai tujuan wisata. Karena pengunjung tidak hanya menikmati lingkungan hutan Taman Nasional Bukit Duabelas tapi pengunjung juga bisa menikmati wisata sosial budaya Suku Anak Dalam yang masih lekat dengan kehidupan tradisional. Dengan banyaknya potensi yang dimiliki Suku Anak Dalam seharusnya dapat menarik minat wisatawan untuk berkunjung. Namun hal tersebut belum dirasakan ketertarikan wisatawan lokal ataupun dari luar untuk berkunjung di Kawasan Suku Anak Dalam Taman Nasional Bukit Dua Belas Kabupaten Sorolangun Provinsi Jambi.

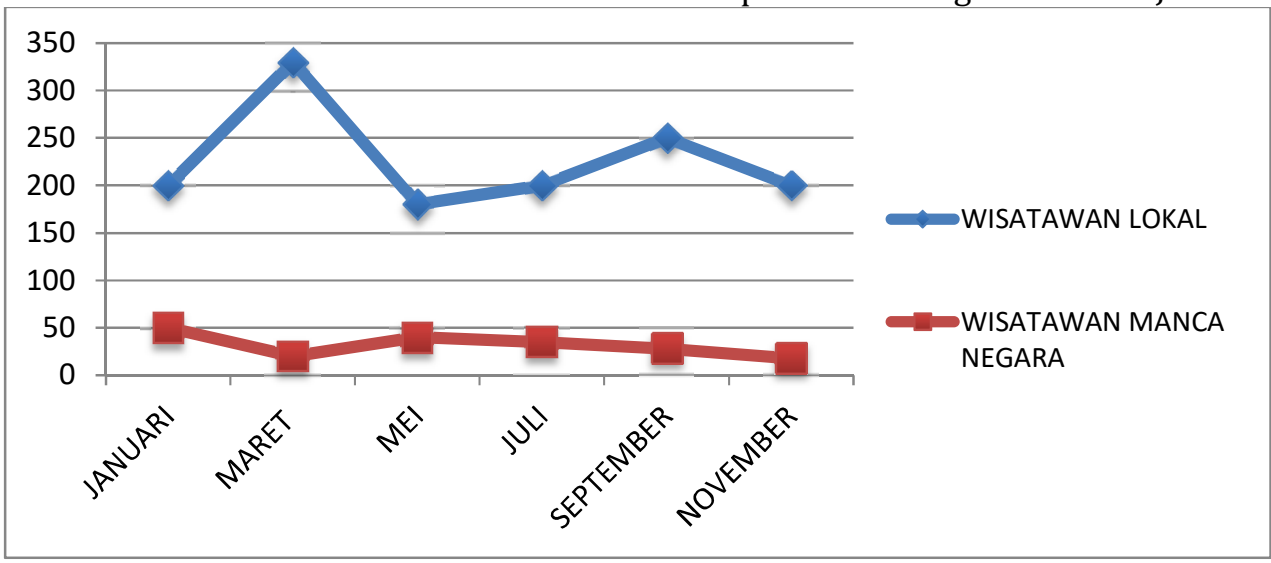

Gambar 1. Data Wisatawan Suku Anak Dalam Tahun 2019 Sumber : Polisi Hutan

Menurut Cox, (dalam Dowling dan Fennel, 2012) tentang Pengelolan pariwisata juga memiliki beberapa prinsip yang harus dilakukan, berikut prinsip-prinsip pengelolaan pariwisata : 
1) Pembangunan dan pengembangan pariwisata haruslah didasarkan pada kearifan lokal dan special local sense yang merefleksikankeunikan peninggalan budaya dan keunikan lingkungan.

2) Preservasi, proteksi dan peningkatan kualitas sumber daya yangmenjadi basisi pengembangan kawasan pariwisata.

3) Pengembangan antraksi wisata tambahan yang mengakar padakhasan budaya lokal.

4) Pelayanan kepada wisatawan yang berbasis keunikan budaya dan lingkungan lokal.

5) Memberikan dukungan dan legitimasi pada pembangunan danpengembangan pariwisata jika terbukti memberikan manfaat positif,tetapi sebaliknya mengendalikan atau menghentikan aktivitaspariwisata tersebut jika melampaui batas.

Merujuk pada penjelasan di atas dapat diambil kesimpulan bahwa pengelolaan merupakan sekelompok orang yang bekerja sama untuk mencapai sebuah tujuan. Pengelolaan disini terkait tentang pengelolaan kawasan wisata pemukiman Suku Anak Dalam dimana pihak-pihak yang terlibat didalam pengelolaan kawasan wisatamempunyai peranan dan tanggung jawab penuh dalam mengatur segala sesuatuyang menyangkut tentang kawasan pemukiman Suku Anak Dalam agar dapat menarik minat wisatawan untuk berkunjung.

\section{METODE PENELITIAN}

Pendekatan yang digunakan dalam penelitian ini adalah pendekatan kualitatif yang bersifat deskriptif. Penelitian kualitatif adalah prosedur penelitian yang menghasilkan data deskriptif berupa kata-kata tertulis atau lisan dari orang-orang dan perilaku yang dapat diamati (Bogdan dan Tylor, 1990 dalam Sugiyono 2013).

Penelitian ini akan dilaksanakan dikawasan pemukiman Suku Anak Dalam Kabupaten Sorolangun Propinsi Jambi. Pemilihan lokasi ini sebagai tempat penelitian dilakukan secara sengaja dengan pertimbangan daerah ini mempunyai kawasan cagar alam
Bukit Dua belas wisata yang sangat indah sebagai tempat bermukim Suku Anak Dalam (SAD).

Sumber data dibagi menjadi, 1) Sumber data primer yakni data yang diperoleh langsung dari sumber pertama. Data primer dalam penelitian ini terutama akan diperoleh dengan melalui pengamatan dan wawancara sehingga nantinya akan diperoleh jawaban dari responden maupun informan yang nyata dan sesuai fokus penelitian. 2) Data Sekunder antara lain mencakup dokumen dokumen resmi, buku buku, hasil penelitian yang berwujud laporan.

Adapun teknik pengumpulan data yang peneliti gunakan dalam penelitian ini adalah: 1) Observasi, Menurut Moleong (2013) Observasi adalah pengamatan dan pencatatan secara sistematis terhadap fenomena-fenomena yang di selidiki. Observasi dilakukan secara langsung ke lapangan mengetahui dan mengamati Bagaimana Pengelolaan Kawasan Wisata Suku Anak Dalam (Studi Pada Taman Nasional Bukit DuaBelas Kabupaten Sorolangun Propinsi Jambi). 2) Wawancara (FGD), Proses komunikasi dipasangkan dengan tujuan serius dan telah ditentukan dirancang untuk bertukar perilaku dan melibatkan tanya jawab. 3) Studi Dokumen, Studi dokumen adalah metode pengumpulan data yang tidak ditujukan langsung kepada subjek penelitian. Studi dokumen adalah jenis pengumpulan data yang meneliti berbagai macam dokumen yang berguna untuk bahan analisis.

Analisis data proses penyederhanaan data ke dalam bentuk yang lebih mudah dibaca dan dikembangkan guna mencari makna dan maksud dari hasil penelitian. Semua data yang didapat dari hasil observasi dan wawancara kemudian dikumpulkan dan disusun secara sistematis serta diklarifikasi atau di urutkan data ke dalam pola, kategori, dan satuan uraian dasar sehingga muncul data yang relevan dengan permasalahan penelitian dan disajikan secara deskriptif serta di analisis secara kualitatif, analisis data secara kualitatif ini dimaksudkan untuk memberikan gambaran secara mendalam dari suatu gejala sosial tertentu (Moleong, 2010).

Pemeriksaan terhadap keabsahan data pada dasarnya, selain digunakan untuk menyanggah balik yang dituduhkan kepada penelitian kualitatif yang mengatakan tidak ilmiah, juga merupakan sebagai unsur yang 
tidak terpisahkan dari tubuh pengetahuan penelitian kualitatif (Moleong, 2017). Keabsahan data dilakukan untuk membuktikan apakah penelitian yang dilakukan benar-benar merupakan penelitian ilmiah sekaligus untuk menguji data yang diperoleh. Uji keabsahan data dalam penelitian kualitatif meliputi uji, credibility, transferability, dependability, dan confirmability (Sugiyono, 2013)

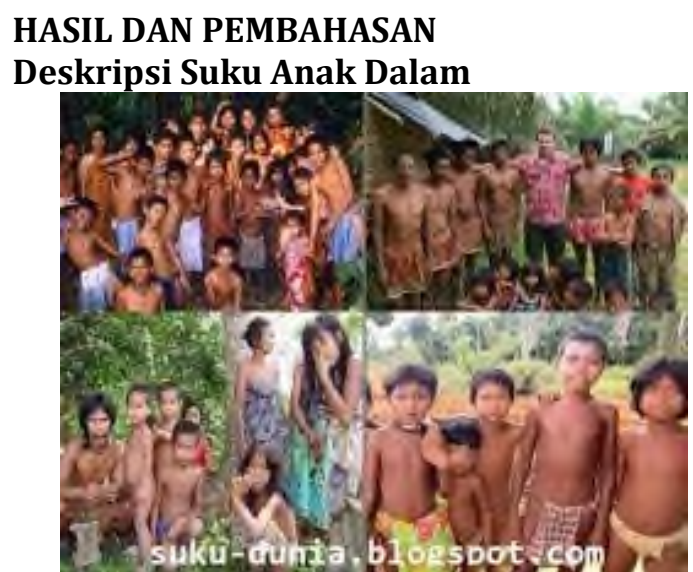

Gambar 2. Suku Anak Dalam (Sukudunia.blogspot.com)

Berbagai penamaan atau penyebutan yang merujuk pada entitas Orang Rimba adalah antara lain Orang Kubu, Suku Anak Dalam, dan Orang Rimba. Dua yang pertama merupakan penamaan yang diberikan orang luar, sedangkan "Orang Rimba" merupakan penyebutan oleh mereka sendiri. Berbagai penamaan tersebut adalah sebagai berikut: $\mathrm{Kubu}$; merupakan sebutan yang paling popular digunakan, terutama oleh orang Melayu dan masyarakat internasional. Kubu dalam bahasa Melayu memiliki makna peyorasi seperti primitif, bodoh, kafir, kotor dan menjijikan. Sebutan kubu telah terlanjur populer terutama oleh berbagai tulisan pegawai colonial dan etnografer pada awal abad ini. Suku Anak Dalam; sebutan ini digunakan oleh Pemerintah melalui Kementerian Sosial. Anak Dalam memiliki makna orang terbelakang yang tinggal dipedalaman, karena itu dalam perspektif pemerintah mereka harus dimodernisasikan dengan mengeluarkan mereka dari hutan dan dimukimkan melalui program pemberdayaan.

Orang Rimba; adalah sebutan yang digunakan oleh etnik ini yang menyebut dirinya. Makna tersebut adalah menunjukan jati diri mereka sebagai etnis yang mengembangkan kebudayaan yang tidak bisa lepas dari hutan. Sebutan ini adalah yang paling proporsional dan obyektif karena didasarkan kepada konsep Orang Rimba itu sendiri dalam menyebut dirinya.

Lokasi permukiman Orang Rimba di Bukit Suban terletak di Kecamatan Air Hitam, Kabupaten Sarolangun. Orang Rimba di lokasi ini dapat dijumpai di sekitar pasar yang berdekatan dengan Kantor Desa, khususnya pada Hari Selasa. Pada hari tersebut warga KAT Bukit Suban menjual berbagai hasil kebun mereka seperti karet dan sebagainya. Hasil penjualan tersebut digunakan untuk membeli kebutuhan hidup seperti beras, kebutuhan memasak, rokok, dan sebagainya. Pada umumnya mereka menggunakan sepeda motor milik sendiri sebagai alat transportasi. Sebagian besar juga sudah memiliki telepon genggam.

Sebagian besar warga memiliki mata pencaharian sebagai penyadap karet. Dalam satu bulan mereka bisa menyadap karet hingga 3 kwintal dengan harga per kilogram sebesar Rp10.000.

Ada juga warga yang mendapatkan bantuan raskin dari pemerintah. Bantuan dari berupa 8 unit rumah yang dibangun dekat dengan perbatasan Taman Nasional Bukit Dua Belas yang menjadi tempat asal tinggal mereka.

Berdasarkan informasi dari Temenggung, pernah ada warga yang sampai kuliah di Jogja namun sampai sekarang tidak kembali lagi ke kampung halamannya. Setiap hari Selasa KAT di Dusun Bukit Suban pergi ke pasar untuk membeli kebutuhan sehari-hari seperti beras, jajanan, sayur dan sebagainya. Jarak tempat tinggal mereka ke pasar sekitar $5 \mathrm{~km}$. Untuk menuju puskesmas ditempuh dengan jarak 10 km. Jika mereka berobat di Puskesmas tidak dikenakan biaya, namun kebiasaan untuk berobat kepada dukun kampung masih dijalankan.

\section{Kelembagaan}

Suku Anak Dalam (SAD) merupakan suku asli yang berada dikawasan Bukit Dua Belas Provinsi Jambi. Masyarakat Suku Anak Dalamhidup dan berkembang di daerah pedalaman hutan Taman NasionalBukit Duabelas yang kemudian juga mengembangkan kebudayaan yangterlihat dari unsur-unsur budaya seperti sistem religi, sistem organisasimasyarakat, sistem kekerabatan, 
hingga sistem mata pencaharian.Semua sistem tersebut memiliki peran dalam membentuk karakter, polahidup, serta pola pikir masyarakat Suku Anak Dalam, dalam kehidupansehari-hari di dalam hutan. Tidak banyak penjelasan asal usul SukuAnak Dalam ini, namun terdapat beberapa versi dari para ahli tentangasal Suku Anak Dalam. Sebagai kelompok sosial budaya bersifat lokal,selanjutnya oleh pemerintah di tempatkan bagian dari Suku Anak Dalam(SAD) atau Komunitas Adat Terpencil (KAT) dengan ciri-ciri:

a) Berbentuk komunitas kecil, tertutup, dan homogen.

b) Pranata sosial bertumpu pada hubungan kekerabatan.

c) Pada umumnya terpencil secara geografis dan relatif sulitdijangkau.

d) Pada umumnya masih hidup dengan sistem ekonomi subsisten.

e) Peralatan dan teknologi sederhana.

f) Ketergantungan pada lingkungan hidup dan sumber daya alamsetempat relatif tinggi.

g) Terbatasnya akses pelayanan sosial, ekonomi, dan politik.

\section{Pengelolaan Kawasan Wisata}

Pengelolaan kawasan wisata sangat berpengaruh dalam kunjungan wisatawan. Secara umum pengelolaan merupakan kegiatan merubah sesuatu hingga menjadi baik atau memiiki niai-nilai yang tinggi dari semula. Pengelolaan dapat juga diartikan sebagai untuk melakukan sesuatu agar lebih baik sesuai serta cocok dengan kebutuhan sehingga lebih bermanfaat. Pengelolaan berarti proses, cara, perbuatan, pengelola, proses melakukan kegiatan tertentu dengan menggerakkan tenaga orang lain, proses yang membantu merumuskan kebijakan dan tujuan organisasi, proses yang memberikan pengawasan pada semua hal yang terlibat dalam pelaksanaan kebijakan dan pencapaian tujuan. Sedangkan Menurut Leiper dalam Pitana pengelolaan merujuk kepada seperangkat peran yang dilakukan oleh seseorang atau sekelompok orang atau bisa juga merujuk kepada fungsifungsi manajemen tersebut antara lain, planning(perencanaan), diecting (mengarahkan), organising (termasuk coordinating), dan controling (pengawasan).
Pengelolaan juga dapat diartikan sebagai manajemen. Manajemen adalah sebagai suatu proses yang diterapkan oleh individu atau kelompok dalam upayaupaya koordinasi untuk mencapai suatu tujuan. Pengertian tersebut dalam skala aktifitas juga dapat diartikan sebagai aktifitas menerbitkan, mengatur, dan berpikir yang dilakukan oleh seseorang, sehingga mampu mengemukakan, menata dan merapikan segala sesuatu yang ada disekitarnya, mengetahui perinsip-perinsipnya serta menjadi hidup selaras dan serasi dengan yang lain. Dalam pengelolaan pariwisata ada tiga aktor penting penggerak pariwisata yaitu pemerintah, masayarakat dan swasta. Ketiga aktor tersebut berhak mengelola kawasan wisata yang ada.

Pengelolan pariwisata juga memiliki beberapa prisip yang harus dilakukan. Menurut Cox (1985) dalam Pitana (2009) pengelolaan pariwisata harus memperhatikan prinsipprinsip sebagai berikut :

1. Pembangunan dan pengembangan pariwisata haruslah didasarkan pada kearifan local dan special local sense yang merefleksikan keunikan peninggalan budaya dan keunikan lingkungan.

2. Preservasi, proteksi, dan peningkatan kualitas sumber daya yang menjadi basis pengembangan kawasan pariwisata.

3. Pengembangan atraksi wisata tambahan yang mengakar pada khasanah budaya lokal.

4. Pelayanan kepada wisatawan yang berbasis kepada keunikan budaya dan lingkungan lokal.

5. Memberikan dukungan ddan legitimasi pada pembangunan dan pengembangan pariwisata jika terbukti memberikan manfaat positif, tetapi sebaliknya mengendalikan dan/atau menghentikan aktivitas pariwisata tersebut jika melampui ambang batas lingkungan alam atau akseptabilitas sosial walaupun di sisi lain mampu meningkatkan pendapatan masyarakat.

Merujuk pada penjelasan di atas dapat diambil kesimpulan bahwa pengelolaan merupakan sekelompok orang yang bekerja sama untuk mencapai sebuah tujuan. Pengelolaan disini terkait tentang pengelolaan kawasan wisata pemukiman Suku Anak Dalam dimana pihak-pihak yang terlibat didalam pengelolaan kawasan wisata mempunyai 
peranan dan tanggung jawab penuh dalam mengatur segala sesuatu yang menyangkut tentang kawasan pemukiman Suku Anak Dalam agar dapat menarik minat wisatawan untuk berkunjung

Pengelolaan kawasan wisata pemukiman Suku Anak Dalam ini melibatkan pemerintah dan masyarakat. Sebagai kelompok masyarakat dalam kehidupannya tidak lepas dari yang namanya kebudayaan. Kebudayaan adalah keseluruhan sistem gagasan, tindakan dan hasil karya manusia dalam kehidupan masyarakat yang dijadikan milik diri manusia dengan belajar. Kebudayaan memiliki tiga wujud yaitu: 1) Wujud kebudayaan sebagai suatuu kompleks dari ide, gagasan, nilai norma, peraturan dan sebagainya. 2) Wujud kebudayaan sebagai suatu komplek aktivitas serta tindakan berpola dari manusia dalam masyarakat. 3) Wujud kebudayaan sebagai benda-benda hasil karya manusia. Dalam hal ini, antara masyarakat dan pemerintah memiliki nilai-nilai, norma, dan peraturan sendiri dalam pengelolaan kawasan Suku Anak Dalam.

\section{SIMPULAN}

Pengelolaan kawasan wisata Suku Anak Dalam (SAD) sudah memberikan kenyaman kepada para pengunjung tanpa mengusik atau mengganggu ekosistem atau keaslian dari tempat wisata tersebut. Dengan adanya pengelolaan wisata edukasi ini akan menambah pendapatan asli daerah (PAD) dalam bidang kepariwisataan. Hal inilah yang harus dipertahankan dan dijaga akan lingkungan kebudayaanya agar nantinya muncul objek wisata yang lainnya. Dalam Pengelolaan Kawasan Wisata perlu juga diadakannya sebuah evaluasi bagi tingkat pengunjung wisata, agar stabilitas ekosistem wisata tidak menurun dan tetap berpegang teguh pada kualitas yang diberikan.

\section{DAFTAR PUSTAKA}

Arikunto, S. (2006). Prosedur Penelitian Suatu Pendekatan Praktik. Jakarta: Rineka Cipta.

Bogdan, R dan Taylor, S. (1992). Pengantar Metode Kualitatif. Surabaya: Usaha Nasional

Gelgel, P. (2009). Industri Pariwisata Indonesia dalam Globalisasi Perdagangan Jasa Implikasi Hukum dan Antisipasinya, Bandung: PT. Refika Aditama,

Girsang, H.D.. (2013). Analisis Strategi Pengembangan Objek Wisata Air Terjun
Sipiso-Piso, Artikel Publikasi, Belum diterbitkan: Universitas Sumatera Utara

Kania, A. (2013). Ensiklopedia Mini Manajemen Kepariwisataan. Bandung: CV Angkasa.

Kasmir dan Jakfar. (2004). Studi Kelayakan Bisnis, Jakarta: Kencana.

Koentjaraningrat. (2009). Pengantar Ilmu Antropologi. Jakarta: RinekaCipta.

Lubis, F.R.A., Suharyanto, A., Effendy, R., Meidasari, V.E., Shahnaz, L. (2020). Role of Facebook Advertising in Promoting Tourism in Asia. International Journal of Psychosocial Rehabilitation

Maharani, I. (2016). Analisis Kelayakan Potensi Ekowisata Pada Kawasan Wisata Alam Bungi Kecamatan Kokalukuna Kota Baubau, Artikel Publikasi.Universitas Holu Oleo: belum diterbitkan,

Meriatul, I, Abdillah, H.Y, dan Hakim, L. (2015). Analisis PengembanganWisata Pantai Indah Popoh sebagai Daerah Tujuan Wisata Kabupaten Tulungagun. Jurnal Administrasi Bisnis (JAB), Vol. 26 No. 2 September 2015.

Moleong, L. J. (2010). Metodologi Penelitian Kualitatif, Bandung: Remaja Rosda

O’Brien, J.A. (2005). Pengantar Sistem Informasi. Jakarta: Salemba Empat,

Pendit, N.S. (1999). Ilmu Pariwisata Sebuah Pengantar Perdana. Jakarta : Pradya Paramita.

Pendit, N.S. (2003). Ilmu Pariwisata sebuah Pengantar Perdana. Jakarta: PT Pradnya Paramita

Pitana, I. G. dan Diarta, I.K.S. (2009). Pengantar Ilmu Pariwisata. Yogyakarta : Penerbit Andi.

Putra, H.S.A., (2004). "Kearifan Tradisional dan Lingkungan Sosial”, makalah pada seminar sehari "Forum Peduli Tradisi" diselenggarakan oleh Bidang Pelestarian dan Pengembangan Kebudayaan, Kementerian Kebudayaan dan Pariwisata, di Jakarta,16 Februari 2004.

Putra, H.S.A., (2006). "Etnosains, Etnotek, dan Etnoart: Paradigma Fenomenologis untuk Revitalisasi Kearifan Lokal", makalah pada seminar 'pemanfaatan Hasil Riset UGM dalam Mendukung Peningkatan Daya Saing Indonesia", diselenggarakan oleh Lembaga Penelitian dan Pengabdian Masyarakat UGM di Yogtakarta, 28 November 2006.

Putra, H.S.A., (2006). Esei-Esei Antropologi:Teori, Metodologi dan. Etnografi. Yogyakarta: KEPEL PRESS

Subagyo. A. (2007). Studi Kelayakan Teori dan Aplikasi.Jakarta: PT. Elex Media Komputindo,

Sugiyono, (2013), Metodelogi Penelitian Kuantitatif, Kualitatif Dan R\&D. Bandung: ALFABETA

Suharyanto, A. Febryani, A. Wiflihani \& Batubara, B.M. (2019). Village Government Policy on 
Tourism Management in Situngkir Village Research Article in Proceedings of the 2nd International Conference on Social Sciences and Interdisciplinary Studies (formerly ICCSSIS), ICCSIS 2019, 24-25 October 2019, Medan, North Sumatera, Indonesia

Sujali. (1989). Geografi Pariwisata dan Kepariwisataan, Diklat Kuliah, Yogyakarta: Fakultas Geografi UGM

Sunyoto, D. (2014).Studi Kelayakan Bisnis, Yogyakarta: CAPS

Sutojo, S. (1996). Studi Kelayakan Proyek, Jakarta: Anggota IKAPI

Tangkilisan, H.N.S. (2005). Manajemen Public. Jakarta: Gramedia Widiasarana Indonesia.
Umar, H. (2008) .Strategic Management In Action. Jakarta: Gramedia Pustaka Utama.

Vitasurya, V.R. (2016). Wisdom for Sustainable Development of Rural Tourism, Case on Kalibiru and Lopati Village, Province of Daerah Istimewa Yogyakarta.Procedia (Social and Behavioral Sciences), 97-108.

Wardiyanta. (2006). Metode Penelitian Pariwisata, Yogyakarta: CV. Andi Offset

Yoeti, O.A. (2006). Pengantar Ilmu Pariwisata. Bandung : Angkasa. 